\title{
Toxicological Risk Assessment of Lead (Pb) Contamination in Public Water System in Lagos Metropolis, Nigeria
}

\author{
Olusola Togunde, Tam-Miette Dawari Briggs, Nnamdi Henry Amaeze, Henry Ebele Obanya* \\ Environmental Toxicology and Pollution Management Unit, Department of Zoology, University of Lagos, Lagos, Nigeria \\ Email: *henryobanya@rocketmail.com
}

How to cite this paper: Togunde, O., Briggs, T.-M.D., Amaeze, N.H. and Obanya, H.E. (2018) Toxicological Risk Assessment of Lead $(\mathrm{Pb})$ Contamination in Public Water System in Lagos Metropolis, Nigeria. Journal of Environmental Protection, 9, 1393-1407.

https://doi.org/10.4236/jep.2018.913086

Received: November 7, 2018

Accepted: December 14, 2018

Published: December 17, 2018

Copyright (๑) 2018 by authors and Scientific Research Publishing Inc. This work is licensed under the Creative Commons Attribution International License (CC BY 4.0).

http://creativecommons.org/licenses/by/4.0/

(c) (i) Open Access

\begin{abstract}
Study Background: Lead continues to be a significant public health problem in developing countries, where there are considerable variations in the sources and pathways of exposure. Aim: This study investigates the level of lead in drinking water sources in Shomolu, Yaba and Bariga areas of Lagos State, Nigeria and the human risk exposure using a mice model. Materials and Methods: Water samples were collected in public water sources (borehole, sachet water, bottle water and tap water) and analyzed for lead using Flame Atomic Absorption Spectrophotometer (Varian model-AA240FS) equipped with a lead hollow cathode lamp. Contamination factor was determined. Healthy Mature female albino-mice, weighing $25.3 \pm 2.5 \mathrm{~g}$ were exposed to the contaminated drinking water for 28 days to the different concentrations of lead nitrate: $1 \mathrm{mg} / \mathrm{l}, 10 \mathrm{mg} / \mathrm{l}, 50 \mathrm{mg} / \mathrm{l}, 500 \mathrm{mg} / \mathrm{l}$ and $1000 \mathrm{mg} / \mathrm{l}$. Blood and liver were collected for hematology liver function test and histopathology. Results: Lead concentrations in public water sources in Shomolu, Bariga and Yaba areas of Lagos State were below $5.0 \mu \mathrm{g} / \mathrm{l}$ and contamination factor were less than 1.0. At $1.0 \mathrm{mg} / \mathrm{l}(1000 \mu \mathrm{g} / \mathrm{l})$ Lead exposure, the relative weight increase in this group (as compared to the controlled group) was very slow, up to the $14^{\text {th }}$ day (with weight loss of $3.17 \mathrm{~g}$ and relative weight loss of $23.1 \%$ ), then increased up to the $28^{\text {th }}$ day (with weight loss of $7.34 \mathrm{~g}$, and relative weight gain of $18.4 \%$ ). At $50.0 \mathrm{mg} / \mathrm{l} \mathrm{Lead}$ exposure, there was a rapid weight decrease, a greater relative weight loss was experienced at the $14^{\text {th }}$ day (weight gain, $1.36 \mathrm{~g}$ and $67.0 \%$ relative weight loss), then there was weight recovery at the $28^{\text {th }}$ day (weight gain of $4.60 \mathrm{~g}, 25.8 \%$ relative weight loss). The $100.0 \mathrm{mg} / \mathrm{l}$ Lead exposed group showed steady decrease in weight, $14^{\text {th }}$ day had a weight gain of $2.02 \mathrm{~g}$ and relative weight loss of $51.0 \%$ while the $28^{\text {th }}$ day had 2.10 weight gain and $66.1 \%$ weight loss respectively. In the $500.0 \mathrm{mg} / \mathrm{l} \mathrm{Lead} \mathrm{expo-}$ sure group, a similar trend was observed as with $1.0 \mathrm{mg} / \mathrm{l}$ and $50 \mathrm{mg} / \mathrm{l} \mathrm{Lead}$
\end{abstract}


exposures, showing greater weight loss at the $14^{\text {th }}$ day $(2.14 \mathrm{~g}$ and $151.9 \%$ weight loss), as compared to the $28^{\text {th }}$ day exposure (1.36 $\mathrm{g}$ and $121.9 \%$ weight loss respectively). Alanine aminotransferase (ALT) and Akaline phosphatase (ALP) in the control group increased with time, but these had a different trend in the exposed groups. The RBC decreased with increase in concentrations from $1.0 \mathrm{mg} \cdot 1$ to $50.0 \mathrm{mg} / \mathrm{l} \mathrm{Lead} \mathrm{exposures,} \mathrm{after} \mathrm{which} \mathrm{it} \mathrm{increases} \mathrm{at}$ $100.0 \mathrm{mg} / \mathrm{l}, 500.0 \mathrm{mg} / \mathrm{l}$ and $1000 \mathrm{mg} / \mathrm{l}$. The highest RBC was noticed at the highest exposure concentration at the $28^{\text {th }}$ day with $\mathrm{RBC}$, much higher than the control. The highest WBC was noticed at the highest exposure concentration at the $28^{\text {th }}$ day with WBC, $8.77 \pm 2.36\left(\times 10^{9} / \mathrm{L}\right)(\mathrm{p}<0.05)$. The $28^{\text {th }}$ day, $100.0 \mathrm{mg} / \mathrm{L}$ exposed mice's liver had cellular vacuolization and mild necrosis. At $14^{\text {th }}$ and $28^{\text {th }}$ day of exposure, the $500.0 \mathrm{mg} / \mathrm{L}$ and $1000.0 \mathrm{mg} / \mathrm{L}$ exposed mice had significant liver pathological alterations including the presence of polymorphic nuclei, blood vessel congestion, cellular vacuolization and severe necrosis. Conclusion: Lead induces hematological disturbances, liver histological alterations and change in weight in mice. These become obvious as exposure concentration increases with time. Continuous monitoring of municipal water pipeline reticulation should be ensured to prevent incidence of seepage of toxicants such as lead into domestic water sources.

\section{Keywords}

Contamination, Lead, Hematology, Histopathology

\section{Introduction}

Lagos, the most industrialized, populous and the fastest growing city in Africa, is currently facing a water management crisis [1]. Due to poor planning, lack of adequate infrastructure, insufficient funds, and a poor governance and regulatory framework, there is a vast demand gap of 330 MGD [1]. As such, only $10 \%$ of the population in Lagos is being served by the public water utility, Lagos Water Corporation [1]. The rest of the population gain access to water either from private boreholes or from informal private sector participants such as water vendors. This situation is further worsened by certain factors such as rapid population growth, corruption, climate change, unreliable electricity, inadequate enforcement, and water leakages and theft that cause $60 \%$ unaccounted-for-water losses. As a result, citizens experience water shortages, water pollution, inadequate sanitation and wastewater treatment, and water injustice and inequality. Due to high industrial and commercial activities and increasing population, pollution is often a major problem.

There has been a series of lead poisonings in Zamfara State, Nigeria, leading to the deaths of at least 163 people between March and June 2010, including 111 children [2]. Independent News Media [3] reported the health ministry figures as 355 cases, with 46 percent proving fatal [2]. This was due to unsafe mining and ore processing. Just five years later, in 2015, between April and May 2015, 28 
children in Kawo and Magiro, two remote villages in Niger State, mysteriously died days after suffering symptoms of convulsions, insomnia and hallucinations, due to lead-rich gold mining [4]. Presently, heavy metals such as lead pose no health risk in Lagos State as compared to other states or regions, but if the right monitoring and management practices are not continually put in place, the case could be different [5]. However, if the concentration of these heavy metals surpasses the maximum admissible levels as stipulated by various organisations such as World Health Organization (WHO), American Public Health Association, then plant and animal health and developments may be affected because of malfunctions caused by bio-concentration of the heavy metals [6] [7].

Lead continues to be a significant public health problem in developing countries, where there are considerable variations in the sources and pathways of exposure [7]. For example, in many Latin American countries, leaded paint is not a significant source of recurrent exposure, whereas lead-glazed ceramics are such a source [8]. Exposure attributable to miscellaneous sources may be even more significant than universal exposure associated with leaded petrol, especially for people living in poverty. Exposure to lead from lead mining, smelting, battery factories and cottage industries is a significant environmental hazard in developing countries [9]. Unlike overt lead toxicity, where there is usually one identifiable source, low-level environmental exposure to lead is associated with multiple sources (petrol, industrial processes, paint, solder in canned foods, water pipes) and pathways (air, household dust, street dirt, soil, water, food) [10]. Evaluation of the relative contributions of sources is therefore complex and likely to differ between areas and population groups. Where lead derived from petrol comprises the major part of atmospheric lead it is a significant contributor to the body lead burden and is the most widely distributed source of the metal in the environment [11]. It is thus desirable to phase out the use of lead additives in fuels as quickly as possible on the global scale.

Atmospheric lead that is deposited in soil and dust may then be ingested by children and may substantially raise their blood lead levels [8]. Signs of acute intoxication, include dullness, restlessness, irritability, poor attention span, headaches, muscle tremor, abdominal cramps, kidney damage, hallucinations, loss of memory and encephalopathy. These occur at blood lead levels of 100 $120 \mu \mathrm{g} / \mathrm{dl}$ in adults and $80-100 \mu \mathrm{g} / \mathrm{dl}$ in children [12] [13]. Signs of chronic lead toxicity, including tiredness, sleeplessness, irritability, headaches, joint pain and gastrointestinal symptoms, may appear in adults at blood lead levels of 50 - 80 $\mu \mathrm{g} / \mathrm{dl}[10]$.

For the population at large, which is not occupationally exposed, food and water are important sources of baseline exposure to lead, in addition to atmospheric lead that is inhaled [11]. Even in countries where considerable efforts have been made to control lead, vast reservoirs of the metal still exist in soil, dust and house paint, and these sources will continue to affect populations for many years [10]. Lead exposure is clearly a global public health issue, but it is only just 
being recognized as a potential problem in many developing countries, with studies only now being reported from Africa, Asia and South America [11].

The aim of this research was to identify levels of lead in drinking water sources in the environment and carry out the human risk assessment using a mice model.

\section{Materials and Methods}

\subsection{Water Sample Collection}

Water samples were collected in public water sources (borehole, sachet water, bottle water and tap water) in Shomolu, Yaba and Bariga areas of Lagos State.

\section{Pre-Treatment of Water Samples}

Water samples were digested according to APHA, 2005. Briefly, $1000 \mathrm{~cm}^{3}$ of well mixed, acid preserved sample was transferred into a beaker. Exactly $50 \mathrm{~cm}^{3}$ of conc $\mathrm{HNO}_{3}$ was added and heated to boiling. This was then evaporated on a hot plate to $20 \mathrm{~cm}^{3}$. Heating and addition of conc. $\mathrm{HNO}_{3}$ continued until after digestion was completed as indicated by a light colour, clear solution. The content was then transferred to $100 \mathrm{~cm}^{3}$ plastic bottles, cooled and diluted to mark. Portions of the solution were used for $\mathrm{Pb}$ determination.

\section{Quantitative Determination of Lead in Water Samples}

In this work, flame atomic absorption spectrophotometer (Varian model-AA240FS) equipped with a lead hollow cathode lamp was used for quantitative determination of $\mathrm{Pb}$ in water samples. Standard calibration curve for the concentration range of $0.001 \mathrm{ppm}^{-2}-2.000 \mathrm{ppm}^{-2}$ was used. This was linear with coefficient of determination of $\mathrm{R}^{2}=0.99$.

Contamination Factor (C.F) of Lead $(P b)$ in Water Samples

The contamination factor (C.F) was calculated by dividing the concentration level of $\mathrm{Pb}$ in each water sample by the background value [14] [15]. In this study, the WHO [6] maximum limit for $\mathrm{Pb}$ in drinking water was selected as background level for the calculation of contamination factors of all the water samples.

\subsection{Test Organism}

The Test Organism used for the study was albino mice (Mus musculus). Fifty-four healthy Mature female albino-mice, weighing $25.3 \pm 2.5 \mathrm{~g}$ were bred in the animal house unit of the Zoological Garden, University of Lagos for the study.

\section{Acclimatization}

The mice were acclimatized in the experimental setup environment for 14 days, before the commencement of the study.

\section{Housing and Feeding}

The mice used for the study were kept in plastic cages measuring $60 \mathrm{~cm} \times 45$ $\mathrm{cm} \times 45 \mathrm{~cm}$. Each cage was divided into 9 equal compartments. Each compartment was deemed to be spacious enough to house a female albino mice without 
stressing out the animal. Thus, each cage contained 9 animals, and a total of 6 cages were used for the study. The cages were kept in the Zoological garden of the University of Lagos. The mean temperature of the surrounding area was $28.0^{\circ} \mathrm{C} \pm 2.0^{\circ} \mathrm{C}$ and the relative humidity was $58.0 \% \pm 5.0 \%$. During the acclimatization as well as the experimental phase of the study, the test subjects were fed with standard mice feed purchased from the Nigerian Institute of Medical Research, Yaba. The constituents of the mice feed are shown in Table 1. The Mice were given Clean Water from the Zoological Garden tap, with a $\mathrm{pH}$ range of 6.80 \pm 2.0 , salinity index of $0.1 \%$ and a temperature range of $22.0^{\circ} \mathrm{C} \pm 5.0^{\circ} \mathrm{C}$.

\subsection{Experimental Setup}

The experiment was setup to compare the histological, liver function enzyme and hematological parameters of mice exposed to Lead with those mice that had no form of exposure to lead, while keeping every other variable constant. For the study, Lead exposure was in form of lead nitrate dissolved in the drinking water fed to the mice. Lead nitrate salt was gotten from the Chemistry Department of the University of Lagos. The salt was dissolved into five (5) concentrations to give a lead concentration exposure of: $1 \mathrm{mg} / \mathrm{l}, 10 \mathrm{mg} / \mathrm{l}, 50 \mathrm{mg} / \mathrm{l}, 500 \mathrm{mg} / \mathrm{l}$ and $1000 \mathrm{mg} / \mathrm{l}$. The controls were not given any water contaminated with dissolved Lead nitrate.

Thus, the experimental subjects were classified based on the concentration of their exposure: 0\% (Control) group, $1 \mathrm{mg} / \mathrm{l}$ group, $50 \mathrm{mg} / \mathrm{l}$ group, $100 \mathrm{mg} / \mathrm{l}$ group, $500 \mathrm{mg} / \mathrm{l}$ group and $1000 \mathrm{mg} / \mathrm{l}$ group. Each experimental group was made up of 9 animals that were placed in the same cage that has been meticulously compartmentalized. The test subjects were exposed to the contaminated drinking water for 28 days according to the different concentration group they belonged to.

\section{Test Solution}

The various lead exposure concentrations ( $1 \mathrm{mg} / \mathrm{l}, 50 \mathrm{mg} / \mathrm{l}, 100 \mathrm{mg} / \mathrm{l}, 500 \mathrm{mg} / \mathrm{l}$ and $1000 \mathrm{mg} / \mathrm{l}$ ) were prepared from lead nitrate using the following formula:

Table 1. Component of the mice feed used for the study.

\begin{tabular}{ccc}
\hline S/N & Components & Composition \\
\hline 1 & Soya Beans Meal (44\% Protein) & $52.5 \%$ \\
2 & Fish Meal & $15.5 \%$ \\
3 & Distillers Dried Soluble & $7.5 \%$ \\
4 & Wheat Shafts & $5.0 \%$ \\
5 & Animal Fats & $3.0 \%$ \\
6 & Pellet & $2.5 \%$ \\
7 & Di-Calcium Phosphate & $0.5 \%$ \\
8 & Coated Vitamin C & $0.057 \%$ \\
9 & Trace Mineral Mix & 0.075 \\
\hline
\end{tabular}




$$
\begin{gathered}
\text { Number of moles }=\frac{\text { Mass }(x)}{\text { Molar mass }} \\
\text { Molarity }=\frac{\text { Number of Moles }}{\text { Volume }(\mathrm{L})}
\end{gathered}
$$

\section{Sample Collection from Test Subjects}

3 mice from each group were sacrificed on day 0,14 and 28 of the study respectively. $2 \mathrm{ml}$ of blood was collected from the eye region for each mouse using heparinised haematocrit tubes and transferred into properly labelled ethylene diamine tetra-acetic acid (EDTA) anti-coagulant bottles. Also the sacrificed mice were dissected after which liver samples were then collected from each mouse. Each harvested organ was kept in a universal bottle and transported into the laboratory for analysis.

\subsection{Determining Difference in Physiological Weight and Relative Weight}

The physiological weight before exposure (day 0) and after exposure were determined. Then the difference in these weights were obtained (Initial weight of the mice-Wi and final weight-Wf). While, the relative weight change was obtained as the rate of change of the physiological weight in comparison with the control group. This is given with the formulae below:

Relative weight $(\%)=\{$ Experimental group $(\mathrm{Wf}-\mathrm{Wi}) /$ Control group $(\mathrm{Wf}-$ $\mathrm{Wi})\}^{\star} 100$

\subsection{Hematological Studies}

To investigate the effect of lead exposure on the haematological parameters of the mice, their, Platelet (PLT), Red Blood Cell (RBC), White Blood Cell (WBC) and Packed Cell Volume (PCV) indices were estimated using electronic counters. Blood-filled heparinized micro-haematocrit capillary tubes were centrifuged at 12,000 for $5 \mathrm{~min}$ using a micro-haematocrit centrifuge and the haematocrit (Hct) values were read directly. The haemoglobin concentration was measured by the cyan-methaemoglobin method at a wavelength of $540 \mathrm{~nm}$. Concurrently, the Total Red Blood Cell (RBC) was obtained by employing the methods described by Oluah and Ulasi [16]. Mean cell haemoglobin concentration (MCHC), mean cell volume $(\mathrm{MCV})$, and mean cell haemoglobin $(\mathrm{MCH})$ were calculated using the following equations: $\mathrm{MCHC}=(\mathrm{Hb} / \mathrm{PCV}) \times 100, \mathrm{MCH}=(\mathrm{Hb} / \mathrm{RBCC}) \times 10$ and $\mathrm{MCV}=(\mathrm{PCV} / \mathrm{RBCC}) \times 100(11)$.

The activities of the liver enzymes; Alanine Aminotransferase (ALT), Aspartate Aminotransferase (AST), and Alkaline Phosphatase (ALP) were determined using the blood sample. The blood was centrifuged at $5000 \mathrm{rpm}$ for 5 minutes; the plasma sample was then collected and kept at $20^{\circ} \mathrm{C}$. The enzymes activities were determined by colorimetric method. The enzymes were then assayed using reagents obtained from enzyme assay kits. 


\subsection{Histopathology Procedure}

To investigate the effect of lead exposure on the tissues of the mice, the histopathology of liver was studied. After each tissue sample had been properly labelled, they were cut and placed inside a tissue embedding cassette. The tissue samples were then processed using a 24 hours automatic tissue processor for a time ranging from $17-19$ hours. The tissue processor completely fixed the tissue in $10 \%$ formal saline, after which the tissue was dehydrated using isopropyl alcohol. After dehydration, the tissue processor cleared the dehydrating agents using xylene $\mathrm{L}$ and $\mathrm{H}$ and then the tissue was cast in molten paraffin at the end of the 19 hours cycle.

After the tissue samples were removed from the tissue processor, they were embedded in molten paraffin wax that was contained in a plastic disposable embedding mould. The mould was then left to cool to room temperature. The embedded samples were then cut using a microtome and the cut sections were placed on a grease free slide. The slides were in turn placed on a hot plate for 30 minutes to enhance the tissues' adherence to the slides. The slides were then stained using the $\mathrm{H}$ and $\mathrm{E}$ staining method and then slides were there after viewed under the microscope.

\subsection{Statistical Analysis}

The values for the liver function enzymes, weight and hematological parameters of the control and various treatment groups were compared using SPSS 20.0 version.

\section{Results and Discussion}

\subsection{Lead Concentration in Public Water Source in Shomolu, Bariga and Yaba Areas of Lagos}

The major sources of lead exposure in some parts of Nigeria according to [5] are from vehicular pollution from leaded gasoline use, industrial pollution from mining, consumption of Nigerian leaded salt, drinking water absolutely obtained from wells. In this study, lead $(\mathrm{Pb})$ concentrations in milligram per liter measured from public tap water, bole-hole, industrially produced bottle water and sachet water in Shomolu, Bariga and Yaba areas of Lagos State however, showed values below $5.0 \mu \mathrm{g} / \mathrm{l}$ and contamination factor less than 1.0 (Table 2). Unlike cases of lead poisoning in Zamfara and Niger States, there has not been reported

Table 2. Lead concentration in public water source in Shomolu, Yaba and Bariga areas of Lagos.

\begin{tabular}{cccccccccc}
\hline \multirow{2}{*}{ Location } & \multicolumn{1}{c}{ Tap water } & \multicolumn{2}{c}{ Bole hole } & \multicolumn{2}{c}{ Bottle water } & \multicolumn{2}{c}{ Sachet water } \\
\cline { 2 - 9 } & Conc. $(\mu \mathrm{g} / \mathrm{l})$ & C.F & Conc. $(\mu \mathrm{g} / \mathrm{l})$ & C.F & Conc. $(\mu \mathrm{g} / \mathrm{l})$ & C.F & Conc. $(\mu \mathrm{g} / \mathrm{l})$ & C.F \\
\hline \multirow{2}{*}{ Shomolu } & 2.60 & $<1.0$ & 4.24 & $<1.0$ & 0.32 & $<1.0$ & 2.25 & $<1.0$ \\
Bariga & 2.10 & $<1.0$ & 3.91 & $<1.0$ & 0.53 & $<1.0$ & 2.02 & $<1.0$ \\
Yaba & 1.80 & $<1.0$ & 4.02 & $<1.0$ & 0.45 & $<1.0$ & 1.58 & $<1.0$ \\
\hline
\end{tabular}

C.F-Contamination factor; WHO, 2011 estimated maximum lead concentrated limits; $3.8 \mu \mathrm{g} / \mathrm{l} / \mathrm{day}$ for an infant to $10 \mu \mathrm{g} / \mathrm{l} / \mathrm{day}$ for an adult. 
case of lead poisoning in Lagos State.

\subsection{Changes in the Physiological Weight of the Experimental Mice during Exposure to Lead}

Lead poisoning can have significant effects on human and animals. One of these effects is gradual or rapid weight loss or rapid weight gain/obesity. Table 3 shows the changes in physiological weight of the mice exposed to varying concentrations of lead for 14 days and 28 days compared to the pre-treatment period (0 day). There was a steady increase in weight in the controlled group; Mean \pm SD, 0 day, $23.06 \mathrm{~g} \pm 1.46 \mathrm{~g}, \mathrm{p}<0.01,14^{\text {th }}$ day, $27.18 \mathrm{~g} \pm 1.45 \mathrm{~g}, \mathrm{p}<0.01$ and $28^{\text {th }}$ day, $29.26 \mathrm{~g} \pm 0.72, \mathrm{p}<0.01$. At $1.0 \mathrm{mg} / \mathrm{l}$ Lead exposure, the weight also increased as the control but the relative increase (as compared to the controlled group) was very slow, up to the $14^{\text {th }}$ day (with weight loss of $3.17 \mathrm{~g}$ and relative weight loss of $23.1 \%$ ), then increased up to the $28^{\text {th }}$ day (with weight loss of 7.34 $\mathrm{g}$, and relative weight gain of $18.4 \%$ ).

At $50.0 \mathrm{mg} / \mathrm{l}$ Lead exposure, there was a rapid weight decrease, a greater relative weight loss was experienced at the $14^{\text {th }}$ day (weight gain, $1.36 \mathrm{~g}$ and $67.0 \%$ relative weight loss), then there was weight recovery at the $28^{\text {th }}$ day (weight gain of $4.60 \mathrm{~g}, 25.8 \%$ relative weight loss). $100.0 \mathrm{mg} / \mathrm{l}$ Lead exposure showed steady decrease in weight, $14^{\text {th }}$ day had a weight gain of $2.02 \mathrm{~g}$ and relative weight loss of $51.0 \%$ while the $28^{\text {th }}$ day had 2.10 weight gain and $66.1 \%$ weight loss respectively. $500.0 \mathrm{mg} / \mathrm{l} \mathrm{Lead} \mathrm{exposure} \mathrm{had} \mathrm{a} \mathrm{similar} \mathrm{trend} \mathrm{as} 1.0 \mathrm{mg} / \mathrm{l}$ and $50 \mathrm{mg} / \mathrm{l}$ Lead exposures, showing greater weight loss at the $14^{\text {th }}$ day $(2.14 \mathrm{~g}$ and $151.9 \%$ weight loss), as compared to the $28^{\text {th }}$ day exposure (1.36 $\mathrm{g}$ and $121.9 \%$ weight loss respectively) (Table 3 ).

About $70 \%$ of Nigerian children have blood lead levels of about $10 \mu \mathrm{g} / \mathrm{dl}$ [17]. According to the Centers for Disease Control and Prevention [18], the unborn child, bottle-fed babies, preschool children, and occupants of older houses are susceptible to lead from diverse sources. In this study, there was a steady increase in weight in the control group as compared to the exposed. The highest concentration of exposure $(1000.0 \mathrm{mg} / \mathrm{l})$ which is a 100 fold of the WHO guideline [6], showed a different trend; there was little or no increase or loss in weight, up

Table 3. Changes in the weight of the experimental albino mice (Mus musculus) during exposure to lead $(\mathrm{n}=3)$.

\begin{tabular}{|c|c|c|c|}
\hline \multirow{2}{*}{ Conc $(\mathrm{mg} / \mathrm{l})$} & \multicolumn{3}{|c|}{ Weight (g) Mean \pm Standard Deviation (Weight gain or loss, $\%$ diff. from control) $(\Delta \mathrm{W})$} \\
\hline & 0 day & $14^{\text {th }}$ day & $28^{\text {th }}$ day \\
\hline 0.00 & $23.06 \pm 1.46^{* *}$ & $27.18 \pm 1.45^{\star *}(4.12,0.0 \%)$ & $29.26 \pm 0.72^{\star *}(6.20,0.0 \%)$ \\
\hline 1.00 & $27.70 \pm 3.79^{\star *}$ & $31.68 \pm 3.17^{\star \star}(3.17,-23.1 \%)$ & $35.04 \pm 1.36^{\star *}(7.34,+18.4 \%)$ \\
\hline 50.00 & $27.14 \pm 3.27^{\star *}$ & $28.50 \pm 3.84^{\star *}(1.36,-67.0 \%)$ & $31.74 \pm 2.08^{\star *}(4.60,-25.8 \%)$ \\
\hline 100.00 & $26.12 \pm 3.08^{\star *}$ & $28.14 \pm 2.86^{\star *}(2.02,-51.0 \%)$ & $28.22 \pm 1.81^{\star *}(2.10,-66.1 \%)$ \\
\hline 500.00 & $29.02 \pm 4.13^{\star *}$ & $26.88 \pm 2.32^{\star \star}(-2.14,-151.9 \%)$ & $27.66 \pm 3.26^{*}(-1.36,-121.9 \%)$ \\
\hline 1000.00 & $27.14 \pm 1.69^{\star *}$ & $27.12 \pm 1.53^{\star *}(-0.02,-1.0 \%)$ & $23.34 \pm 3.01^{*}(-3.80,-161.3 \%)$ \\
\hline
\end{tabular}

${ }^{*}$ Signifies mean is significant at 0.01 level $(\mathrm{p}<0.01)$ and ${ }^{\star}$ Signifies mean is significant at 0.05 level $(\mathrm{p}<0.05)$. 
to the $14^{\text {th }}$ day, after which the weight loss became very rapid, with the highest relative weight loss of $3.80 \mathrm{~g}$ and $161.3 \%$ respectively (Table 3 ). This is in strong agreement with the study of Allouche et al. [19], who reported that the long-term exposure to low lead concentration might lead to high weight gain and obesity risk. Likewise, Brunton [20], reported common symptoms of acute lead poisoning as gastrointestinal problems, such as constipation, diarrhea, poor appetite, and weight loss. Absorption of large amounts of lead over a short time could cause shock (insufficient fluid in the circulatory system) due to loss of water from the gastrointestinal tract [19].

\subsection{Liver Function Enzyme Responses to Varying Concentrations of Lead for 14 and 28 Days}

The results of the present experiment clearly indicate that acute and long-term exposure to lead nitrate causes significant biochemical alterations, which increases with exposure concentrations and time. Table 4 shows the responses of the liver function enzymes to varying concentrations of lead for 14 and 28 days. The liver function enzymes in the blood; alkaline phosphatase (ALP), alanine aminotransferase (ALT) and aspartate aminotransferase (AST) are indicators of stress condition of the liver. Changes in any of these enzymes relative to the control indicate alteration from normal or health condition.

Alkaline phosphatase (ALP) in the control group increased with time, $14^{\text {th }}$ day, $32.99 \pm 3.11 \mathrm{~g}(\mathrm{p}<0.01), 28^{\text {th }}$ day, $34.24 \pm 5.00 \mathrm{~g}(\mathrm{p}<0.05)$. The trend was slightly different in the exposed groups. Specifically, for those exposed to $1.0 \mathrm{mg} / \mathrm{l}$, the values were $43.39 \pm 1.16 \mathrm{~g}(\mathrm{p}<0.05)$ and $5.75 \pm 0.76 \mathrm{~g}(\mathrm{p}<0.05)$ by day $14^{\text {th }}$ and $28^{\text {th }}$ of exposure respectively. For the $50.0 \mathrm{mg} / \mathrm{l}$ exposure group, ALP was $35.18 \pm 1.12 \mathrm{~g}(\mathrm{p}<0.01)$, and $11.4 \pm 0.55 \mathrm{~g}(\mathrm{p}<0.01)$ after 14 and 28 days exposure respectively. In the $100.0 \mathrm{mg} / \mathrm{l}$ group, it changed from $20.76 \pm$ $0.73 \mathrm{~g}(\mathrm{p}<0.01)$ at day 14 to $9.40 \pm 2.05 \mathrm{~g}(\mathrm{p}<0.05)$ by day $28^{\text {th }}$. For those exposed to $500.0 \mathrm{mg} / \mathrm{l}$, the values were $23.76 \pm 0.73 \mathrm{~g}(\mathrm{p}<0.01)$ and $11.37 \pm 0.93 \mathrm{~g}$ $(\mathrm{p}<0.011)$ by day $14^{\text {th }}$ and day $28^{\text {th }}$ of exposure respectively, while in the 1000.0 $\mathrm{mg} / \mathrm{l}$ exposure group, the value was $58.46 \pm 1.46 \mathrm{~g}(\mathrm{p}<0.01)$ on day $14^{\text {th }}$ and 8.44

Table 4. Hepatic antioxidant enzyme responses to varying concentrations of Lead for 14 and 28 days.

\begin{tabular}{ccccccc}
\hline \multirow{2}{*}{ Conc. $(\mathrm{mg} / \mathrm{l})$} & \multicolumn{2}{c}{ ALP $(\mu / \mathrm{l})($ Mean $\pm \mathrm{SD})$} & \multicolumn{2}{c}{ AST $(\mu / \mathrm{l})($ Mean $\pm \mathrm{SD})$} & \multicolumn{2}{c}{ AL T $(\mu / \mathrm{l})(\mathrm{Mean} \pm \mathrm{SD})$} \\
\cline { 2 - 7 } & $\mathbf{1 4}^{\text {th }}$ day & $\mathbf{2 8}^{\text {th }}$ day & $\mathbf{1 4}^{\text {th }}$ day & $\mathbf{2 8}^{\text {th }}$ day & \multicolumn{1}{c}{$\mathbf{1 4}^{\text {th }}$ day } & $\mathbf{2 8}^{\text {th }}$ day \\
\hline \multirow{2}{*}{0.00} & $32.99 \pm 3.11^{* *}$ & $34.24 \pm 5.00^{*}$ & $29.01 \pm 3.89^{*}$ & $12.15 \pm 2.89^{* *}$ & $2.44 \pm 0.53$ & $3.12 \pm 0.53^{*}$ \\
1.00 & $43.39 \pm 1.16^{* *}$ & $5.75 \pm 0.76^{*}$ & $27.11 \pm 1.08^{* *}$ & $13.62 \pm 0.36^{* *}$ & $18.17 \pm 1.90^{* *}$ & $3.95 \pm 0.11^{* *}$ \\
50.00 & $35.18 \pm 1.12^{* *}$ & $11.4 \pm 0.55$ & $37.53 \pm 1.36^{* *}$ & $41.32 \pm 5.02^{* *}$ & $4.63 \pm 1.49^{*}$ & $4.13 \pm 0.38^{* *}$ \\
100.00 & $20.76 \pm 0.73^{* *}$ & $9.40 \pm 2.05^{*}$ & $26.15 \pm 1.45^{* *}$ & $36.69 \pm 4.76^{* *}$ & $4.17 \pm 0.25^{* *}$ & $3.78 \pm 0.65^{*}$ \\
500.00 & $23.76 \pm 0.73^{* *}$ & $11.37 \pm 0.93^{* *}$ & $27.15 \pm 0.32^{*}$ & $38.24 \pm 1.86^{* *}$ & $28.57 \pm 1.50^{* *}$ & $4.60 \pm 0.65^{* *}$ \\
1000.00 & $58.46 \pm 1.46^{* *}$ & $8.44 \pm 1.91^{*}$ & $38.13 \pm 1.09^{* *}$ & $35.21 \pm 3.04^{* *}$ & $23.29 \pm 2.13^{*}$ & $3.01 \pm 0.10^{* *}$
\end{tabular}

${ }^{*}$ Signifies the mean is significant at 0.01 level $(\mathrm{p}<0.01)$ and ${ }^{*}$ Signifies mean is significant at 0.05 level $(\mathrm{p}<0.05)$. AST - Aspartate aminotransferase; ALT-Alanine aminotransferase; ALP-Alkaline phosphatase. 
$\pm 1.91 \mathrm{~g}(\mathrm{p}<0.05)$ on day $28^{\text {th }}($ Table 4$)$.

Alanine aminotransferase (ALT) in the control group also increased with time, $14^{\text {th }}$ day, $2.44 \pm 0.53 \mathrm{~g}(\mathrm{p}<0.01), 28^{\text {th }}$ day, $3.12 \pm 0.53 \mathrm{~g}(\mathrm{p}<0.05)$. The trend in the exposed groups was different. For those exposed to $1.0 \mathrm{mg} / \mathrm{l}$, the values were $18.17 \pm 1.90 \mathrm{~g}(\mathrm{p}<0.01)$ and $3.95 \pm 0.11 \mathrm{~g}(\mathrm{p}<0.01)$ by day $14^{\text {th }}$ and $28^{\text {th }}$ of exposure respectively. For the $50.0 \mathrm{mg} / \mathrm{l}$ exposure group, ALT was $4.63 \pm$ $1.49 \mathrm{~g}(\mathrm{p}<0.05)$, and $4.13 \pm 0.38 \mathrm{~g}(\mathrm{p}<0.05)$ after 14 and 28 day of exposure respectively. In the $100.0 \mathrm{mg} / \mathrm{l}$ it changed from $4.17 \pm 0.25 \mathrm{~g}(\mathrm{p}<0.01)$ at day $14^{\text {th }}$ to $3.78 \pm 0.65 \mathrm{~g}(\mathrm{p}<0.05)$ by day $28^{\text {th }}$. For those exposed to $500.0 \mathrm{mg} / \mathrm{l}$, the values were $28.57 \pm 1.50 \mathrm{~g}(\mathrm{p}<0.01)$ and $4.60 \pm 0.65 \mathrm{~g}(\mathrm{p}<0.01)$ by day $14^{\text {th }}$ and $28^{\text {th }}$ of exposure respectively, while in the $1000.0 \mathrm{mg} / \mathrm{l}$ exposure group, the value was $23.29 \pm$ $2.13 \mathrm{~g}(\mathrm{p}<0.01)$ on day $14^{\text {th }}$ and $3.01 \pm 0.10 \mathrm{~g}(\mathrm{p}<0.05)$ on day $28^{\text {th }}$ (Table 4$)$.

Aspartate aminotransferase (AST) in the control group decreased with time, $14^{\text {th }}$ day, $29.01 \pm 3.89 \mathrm{~g}(\mathrm{p}<0.05), 28^{\text {th }}$ day, $12.15 \pm 2.89 \mathrm{~g}(\mathrm{p}<0.05)$. The trend was however irregular in the exposed groups. For those exposed to $1.0 \mathrm{mg} / \mathrm{l}$, the value decreased from $27.11 \pm 1.08 \mathrm{~g}(\mathrm{p}<0.01)$ at day $14^{\text {th }}$ to $13.62 \pm 0.36 \mathrm{~g}(\mathrm{p}<$ 0.01 ) by day $28^{\text {th }}$. There was an increase in value for those exposed to $50.0 \mathrm{mg} / \mathrm{l}$ from $37.53 \pm 1.36 \mathrm{~g}(\mathrm{p}<0.01)$ on day $14^{\text {th }}$ to $41.32 \pm 5.02 \mathrm{~g}(\mathrm{p}<0.05)$ by day $28^{\text {th }}$. In the $100.0 \mathrm{mg} / \mathrm{l}$ exposure group there was also an increase in value from 26.15 $\pm 1.45 \mathrm{~g}(\mathrm{p}<0.01)$ at day $14^{\text {th }}$ to $36.69 \pm 4.76 \mathrm{~g}(\mathrm{p}<0.01)$ by day $28^{\text {th }}$. For those exposed to $500.0 \mathrm{mg} / \mathrm{l}$ the values were $27.15 \pm 0.32 \mathrm{~g}(\mathrm{p}<0.05)$ and $38.24 \pm 1.86$ $\mathrm{g}(\mathrm{p}<0.01)$ by day $14^{\text {th }}$ and $28^{\text {th }}$ of exposure respectively, while in the $1000.0 \mathrm{mg} / \mathrm{l}$ exposure group, there was a decrease from $38.13 \pm 1.09 \mathrm{~g}(\mathrm{p}<0.01)$ on day $14^{\text {th }}$ to $35.21 \pm 3.04 \mathrm{~g}(\mathrm{p}<0.01)$ by day $28^{\text {th }}$ (Table 4$)$.

These results in this study, are in agreement with the work of Bharali [15], but not with Allouche et al. [19]. Bharali [21] reported that increased lead concentrations caused increase in serum level of ALT enzyme and caused imbalance of the oxidant status of the cells, which isreflected in the rising level of liver tissue MDA level. Allouche et al. [19] reported that no evident disturbance of serum biochemical liver parameters was observed after long-term lead exposures. The author discounted the incrimination of the long-term lead exposure to risk of atherosclerosis or impairment of liver function.

In this study, alanine aminotransferase (ALT) and akaline phosphatase (ALP) in the control group increased with time, but these had different trend in the exposed groups. ALT is commonly measured clinically as a part of a diagnostic evaluation of hepatocellular injury to determine liver health. Significantly elevated levels of ALT and ALP often suggest the existence of health problems such as viral hepatitis, diabetes, congestive heart failure, liver damage, bile duct problems, infectious mononucleosis, or myopathy.

\subsection{Changes in Hematological Parameters in Mice Exposed to Varying Concentrations of Lead for 14 and 28 Days}

The effects of lead exposure could further be seen in the hematological parame- 
ters as changes in the red blood cell counts, white blood cell count, mean hemoglobin volume and concentration, mean corpuscular volume and concentration and so on. Table 5 and Table 6 show changes in hematological parameters in mice exposed to varying concentrations of Lead for 14 and 28 days.

The Red blood cells (RBC) decreased with increase in concentrations from 1.0 $\mathrm{mg} / \mathrm{l}$ to $50.0 \mathrm{mg} / \mathrm{l}$ Lead exposures, after which it increases at $100.0 \mathrm{mg} / \mathrm{l}, 500.0$ $\mathrm{mg} / \mathrm{l}$ and $1000 \mathrm{mg} / \mathrm{l}$. The highest $\mathrm{RBC}$ was noticed at the highest exposure concentration at the $28^{\text {th }}$ day with $\mathrm{RBC}, 10.43 \pm 1.46(\mathrm{~g} / \mathrm{dL})(\mathrm{p}<0.01)$ much higher than the control. The white blood cells (WBC) took a different trend compared with the RBC, there were steady increase at $1.0 \mathrm{mg} / \mathrm{l}, 50.0 \mathrm{mg} / \mathrm{l}, 100.0 \mathrm{mg} / \mathrm{l}, 500.0$ $\mathrm{mg} / \mathrm{l}$ and $1000.0 \mathrm{mg} / \mathrm{l}$. The highest $\mathrm{WBC}$ was noticed at the highest exposure concentration at the $28^{\text {th }}$ day with WBC, $8.77 \pm 2.36\left(\times 10^{9} / \mathrm{L}\right)(\mathrm{p}<0.05)$ much higher than the control $2.27 \pm 0.81\left(\times 10^{9} / \mathrm{L}\right)(\mathrm{p}<0.05)$. The Mean Corpuscular Volume (MCV) (fL) decreased with increase in concentrations from $1.0 \mathrm{mg} / \mathrm{l}$ to $1000.0 \mathrm{mg} / \mathrm{l}$ Lead exposures. The lowest MCV was noticed at the highest exposure concentration at the $14^{\text {th }}$ and $28^{\text {th }}$ day with MCV, $35.17 \pm 0.91$ (fL) $(\mathrm{p}<0.05)$ and $40.50 \pm 1.37$ (fL) $(\mathrm{p}<0.01)$ respectively, much lower than the controls 39.67 $\pm 0.76(\mathrm{fL})(\mathrm{p}<0.05)$ and $42.73 \pm 0.91(\mathrm{fL})(\mathrm{p}<0.01)$ respectively (Table 5).

Table 5. Mean values and standard deviation of the blood parameters of mice exposed to lead.

\begin{tabular}{ccccccc}
\hline \multirow{2}{*}{ Conc $(\mathrm{mg} / \mathrm{l})$} & \multicolumn{2}{c}{$\mathrm{RBC}(\mathrm{g} / \mathrm{dL})$} & \multicolumn{2}{c}{ WBC $\left(\times 10^{9} / \mathrm{L}\right)$} & \multicolumn{2}{c}{$\mathrm{MCV}(\mathrm{fL})$} \\
\cline { 2 - 7 } & $14^{\text {th }}$ day & $28^{\text {th }}$ day & $14^{\text {th }}$ day & $28^{\text {th }}$ day & $14^{\text {th }}$ day & $28^{\text {th }}$ day \\
\hline 0.00 & $9.17 \pm 0.06^{* *}$ & $8.43 \pm 1.23^{* *}$ & $2.27 \pm 0.81^{*}$ & $2.77 \pm 1.10^{*}$ & $39.67 \pm 0.76$ & $42.73 \pm 0.91^{* *}$ \\
1.00 & $7.02 \pm 0.03^{* *}$ & $7.91 \pm 0.76^{*}$ & $3.77 \pm 0.85^{*}$ & $5.00 \pm 3.61^{*}$ & $39.20 \pm 0.79^{* *}$ & $43.13 \pm 0.59^{* *}$ \\
50.00 & $6.92 \pm 0.10^{* *}$ & $5.67 \pm 0.55^{* *}$ & $3.93 \pm 0.32^{*}$ & $5.93 \pm 0.25^{* *}$ & $38.37 \pm 0.71^{*}$ & $45.07 \pm 0.16^{* *}$ \\
100.00 & $7.05 \pm 0.16^{* *}$ & $6.40 \pm 1.35^{*}$ & $3.73 \pm 0.57^{* *}$ & $6.70 \pm 0.56^{* *}$ & $37.27 \pm 042^{* *}$ & $44.77 \pm 1.06^{* *}$ \\
500.00 & $7.09 \pm 0.14^{* *}$ & $6.70 \pm 1.45^{* *}$ & $4.93 \pm 1.27^{*}$ & $7.60 \pm 2.09^{*}$ & $36.30 \pm 0.72^{* *}$ & $40.47 \pm 0.40^{* *}$ \\
1000.00 & $7.15 \pm 0.11^{* *}$ & $10.43 \pm 1.46^{* *}$ & $5.83 \pm 1.21^{*}$ & $8.77 \pm 2.36^{*}$ & $35.17 \pm 0.91^{*}$ & $40.50 \pm 1.37^{* *}$ \\
\hline
\end{tabular}

${ }^{*}$ Signifies the mean is significant at 0.01 level $(\mathrm{p}<0.01)$ and ${ }^{*}$ Signifies mean is significant at 0.05 level $(\mathrm{p}<0.05)$. RBC-Red Blood Cell $(\mathrm{g} / \mathrm{dL})$; WBC-White Blood Cell $\left(\times 10^{9} / \mathrm{L}\right)$; MCV—Mean Corpuscular Volume (fL).

Table 6. Mean values and standard deviation of the blood parameters of mice exposed to lead.

\begin{tabular}{ccccccc}
\hline \multirow{2}{*}{ Conc $(\mathrm{mg} / \mathrm{l})$} & \multicolumn{2}{c}{$\mathrm{MCH}(\mathrm{Pg})$} & \multicolumn{2}{c}{$\mathrm{MCHC}(\mathrm{g} / \mathrm{dL})}$. & \multicolumn{2}{c}{ HCT (\%) } \\
\cline { 2 - 7 } & \multicolumn{1}{c}{$14^{\text {th }}$ day } & $28^{\text {th }}$ day & $14^{\text {th }}$ day & $28^{\text {th }}$ day & $14^{\text {th }}$ day & $28^{\text {th }}$ day \\
\hline \multirow{2}{*}{0.00} & $15.13 \pm 0.61^{* *}$ & $14.87 \pm 0.16^{* *}$ & $35.83 \pm 0.21^{*}$ & $35.07 \pm 0.16^{*}$ & $37.23 \pm 0.76^{*}$ & $38.63 \pm 0.35^{* *}$ \\
1.00 & $15.17 \pm 0.75^{* *}$ & $14.27 \pm 0.12^{*}$ & $30.43 \pm 1.40^{* *}$ & $33.90 \pm 0.50^{* *}$ & $35.93 \pm 1.06^{* *}$ & $35.60 \pm 1.37^{* *}$ \\
50.00 & $14.88 \pm 0.63^{* *}$ & $14.30 \pm 0.10^{* *}$ & $29.00 \pm 0.46^{*}$ & $31.45 \pm 0.25^{* *}$ & $34.60 \pm 0.72^{* *}$ & $43.07 \pm 0.15^{* *}$ \\
100.00 & $14.77 \pm 0.42^{* *}$ & $14.17 \pm 1.11^{*}$ & $28.47 \pm 1.66^{* *}$ & $32.77 \pm 0.15^{* *}$ & $33.53 \pm 0.94^{* *}$ & $36.97 \pm 5.78^{*}$ \\
500.00 & $14.42 \pm 0.14^{* *}$ & $14.87 \pm 0.46^{* *}$ & $27.27 \pm 1.31^{*}$ & $35.77 \pm 0.16^{* *}$ & $32.37 \pm 1.31^{* *}$ & $34.90 \pm 1.83^{* *}$ \\
1000.00 & $14.13 \pm 0.12^{* *}$ & $15.13 \pm 0.61^{* *}$ & $25.67 \pm 0.97^{* *}$ & $36.13 \pm 0.88^{* *}$ & $30.43 \pm 1.31^{*}$ & $32.20 \pm 0.36^{* *}$
\end{tabular}

${ }^{*}$ Signifies the mean is significant at 0.01 level $(\mathrm{p}<0.01)$ and ${ }^{*}$ Signifies mean is significant at 0.05 level $(\mathrm{p}<0.05)$. MCH-Mean Corpuscular Hemoglobin (Pg); MCHC-Mean Corpuscular Hemoglobin Concentration (g/dL); HCT-Hematocrit (\%). 
The Mean Corpuscular Hemoglobin $(\mathrm{MCH})(\mathrm{Pg})$ decreased very slowly at 1.0 $\mathrm{mg} / \mathrm{l}, 50.0 \mathrm{mg} / \mathrm{l}, 100.0 \mathrm{mg} / \mathrm{l}, 500.0 \mathrm{mg} / \mathrm{l}$ and $1000.0 \mathrm{mg} / \mathrm{l}$ except for the $28^{\text {th }}$ day $500.0 \mathrm{mg} / \mathrm{l}$ and $1000.0 \mathrm{mg} / \mathrm{l}$ exposures, where there were increase in $\mathrm{MCH}$ much greater than the control. The lowest peak was at the $28^{\text {th }}$ day $100.0 \mathrm{mg} / \mathrm{l}$ exposure, $14.17 \pm 1.11(\mathrm{Pg})(\mathrm{p}<0.05)$ and the highest $\mathrm{MCH}$ was at the $28^{\text {th }}$ day 1000.0 $\mathrm{mg} / \mathrm{l}$ exposure, $15.13 \pm 0.61(\mathrm{Pg}),(\mathrm{p}<0.01)$ compared to the control, $14.87 \pm$ 0.16 (Pg), $(\mathrm{p}<0.01)$. The Mean Corpuscular Hemoglobin Concentration (MCHC) $(\mathrm{g} / \mathrm{dL})$ had similar trend as the $\mathrm{MCH}$, decreased at $1.0 \mathrm{mg} / \mathrm{l}, 50.0 \mathrm{mg} / \mathrm{l}, 100.0$ $\mathrm{mg} / \mathrm{l}, 500.0 \mathrm{mg} / \mathrm{l}$ and $1000.0 \mathrm{mg} / \mathrm{l}$ except for the $28^{\text {th }}$ day $500.0 \mathrm{mg} / \mathrm{l}$ and 1000.0 $\mathrm{mg} / \mathrm{l}$ exposures, where there were increase in $\mathrm{MCHC}$ much greater than the control.

The Hematocrit (HCT) (\%) at the $14^{\text {th }}$ day exposure, decreased steadily at 1.0 $\mathrm{mg} / \mathrm{l}, 50.0 \mathrm{mg} / \mathrm{l}, 100.0 \mathrm{mg} / \mathrm{l}, 500.0 \mathrm{mg} / \mathrm{l}$ and $1000.0 \mathrm{mg} / \mathrm{l}$. The highest exposure concentration had the lowest HCT, $30.43 \pm 1.31(\%)$ ( $<<0.01)$, much lower than the control, $37.23 \pm 0.76(\%)(\mathrm{p}<0.05)$. At the $28^{\text {th }}$ day, the hematocrit, initially decreased at $1.0 \mathrm{mg} / \mathrm{l}$, then increased at $50.0 \mathrm{mg} / \mathrm{l}$, before decreasing at 100.0 $\mathrm{mg} / \mathrm{l}, 500.0 \mathrm{mg} / \mathrm{l}$, and $1000.0 \mathrm{mg} / \mathrm{l}$. The highest exposure concentration had the lowest HCT, $32.20 \pm 0.36(\%)(\mathrm{p}<0.01)$, much lower than the control, $38.63 \pm$ $0.35(\%)(\mathrm{p}<0.01)($ Table 6$)$.

These results are in agreement with the study of Oluah and Ulasi [16], that reported increased erythropoiesis in Clarias gariepinus exposed to lead poisoning. The highest $\mathrm{WBC}$ was noticed at the highest exposure concentration at the $28^{\text {th }}$ day with WBC, much higher than the control. Both the red blood cells and white blood cells increased with concentration at 28 day exposure, this also agrees with [16].

Erythropoiesis is stimulated by decreased oxygen in circulation, which is detected by the kidneys, which then secrete the hormone erythropoietin [22]. This hormone stimulates proliferation and differentiation of red cell precursors, which activates increased erythropoiesis in the hemopoietic tissues, ultimately producing red blood cells. Lead poisoning could be associated with hematopoietic toxicity as this occurs as a result of enzymatic inhibition and damage to the barrier between the blood and bone marrow [22]. Increased lead concentrations will directly inhibit certain enzymes including heme synthetase, aminolevulinic acid dehydrogenase, ferrochelatase, 5'nucleotidase, and coproporphyrinogenase. Enzymatic inhibition results in an increase in the concentration of heme precursors (protoporphyrins), metarubricytosis, basophilic stippling, and erythrocytes that are more susceptible to physical damage [22] [23].

\subsection{Histopathological Responses to Varying Concentrations of Lead Exposed Mice for 14 and 28 Days}

The acute and long-term lead exposure can cause significant and irreversible pathological alterations. This was only observed in the liver. Histological examination showed significant alteration in the liver (Table 7). The liver sample from the control group, the $14^{\text {th }}$ and $28^{\text {th }}$ day $1.0 \mathrm{mg} / \mathrm{L}$ and $50 \mathrm{mg} / \mathrm{L}$ exposed groups 
Table 7. Hepatic histopathological responses to varying concentrations of Lead exposed mice for 14 and 28 days.

\begin{tabular}{|c|c|c|c|c|c|c|c|c|c|c|c|c|}
\hline \multirow{2}{*}{$\begin{array}{c}\text { Exposure Conc } \\
(\mathrm{mg} / \mathrm{L})\end{array}$} & \multicolumn{2}{|c|}{ Alteration } & \multicolumn{2}{|c|}{ Polymorphic Nuclei } & \multicolumn{2}{|c|}{ Vessel congestion } & \multicolumn{2}{|c|}{ Vacuolization } & \multicolumn{2}{|c|}{ Mild Necrosis } & \multicolumn{2}{|c|}{ Severe Necrosis } \\
\hline & 14 day & 28 day & 14 day & 28 day & 14 day & 28 day & 14 day & 28 day & 14 day & 28 day & 14 day & 28 day \\
\hline Control & No & No & Abs & Abs & Abs & Abs & Abs & Abs & Abs & Abs & Abs & Abs \\
\hline $1.0 \mathrm{mg} / \mathrm{L}$ & No & No & Abs & Abs & Abs & Abs & Abs & Abs & Abs & Abs & Abs & Abs \\
\hline $50.0 \mathrm{mg} / \mathrm{L}$ & No & No & Abs & Abs & Abs & Abs & Abs & Abs & Abs & Abs & Abs & Abs \\
\hline $100.0 \mathrm{mg} / \mathrm{L}$ & No & Yes & Abs & Abs & Abs & Abs & Abs & Pres & Abs & Pres & Abs & Abs \\
\hline $500 \mathrm{mg} / \mathrm{L}$ & Yes & Yes & Pres & Pres & Pres & Pres & Pres & Pres & Pres & Pres & Pres & Pres \\
\hline $1000.0 \mathrm{mg} / \mathrm{L}$ & Yes & Yes & Pres & Pres & Pres & Pres & Pres & Pres & Pres & Pres & Pres & Pres \\
\hline
\end{tabular}

Abs-absent, Pre-Present.

and $14^{\text {th }}$ day $100.0 \mathrm{mg} / \mathrm{L}$ exposed mice had no significant alterations. By the $28^{\text {th }}$ day of exposure to $100.0 \mathrm{mg} / \mathrm{L}$, the mice liver had cellular vacuolization and mild necrosis. In addition, by the $14^{\text {th }}$ and $28^{\text {th }}$ day of exposure to both $500.0 \mathrm{mg} / \mathrm{L}$ and $1000.0 \mathrm{mg} / \mathrm{L}$ of lead, the mice had significant liver pathological alterations, which include the presence of polymorphic nuclei, blood vessel congestion, cellular vacuolization and severe necrosis.

This was reported by Bharali [21] as shown in this study. Bharali [21] reported 24 hour acute post exposure and also hepatocytes surrounding centrilobular area of liver displayed increased apoptotic morphology and cytoplasmic vacuolation. In this study, the hepatocytes of the control group, the $14^{\text {th }}$ and $28^{\text {th }}$ day $1.0 \mathrm{mg} / \mathrm{L}$ and $50 \mathrm{mg} / \mathrm{L}$ exposed groups and $14^{\text {th }}$ day $100.0 \mathrm{mg} / \mathrm{L}$ exposed mice had no significant alteration. By the $28^{\text {th }}$ day, $100.0 \mathrm{mg} / \mathrm{L}$ exposed mice had cellular vacuolization and mild necrosis. At $14^{\text {th }}$ and $28^{\text {th }}$ day of exposure, the $500.0 \mathrm{mg} / \mathrm{L}$ and $1000.0 \mathrm{mg} / \mathrm{L}$ exposed mice had significant liver pathological alterations including the presence of polymorphic nuclei, blood vessel congestion, cellular vacuolization and severe necrosis.

\section{Conclusion}

In view of these results, it appears that lead induces hematological disturbances, liver histological alterations and change in physiological weight in mice. These become obvious as exposure concentration increases with time. Continuous monitoring of municipal water pipeline reticulation should be ensured to prevent incidence of seepage of toxicants such as lead into domestic water sources. The heavy metal, lead, which is known for these effects, is particularly dangerous to human health and is present in the air, soil, public water system and in food chain. To put an end to cases of lead poisoning in Nigeria, the right monitoring and management practices are necessary. Artisanal ore mining which often releases lead into surrounding environments as seen in the Zamfara State and Niger State case studies of lead poisoning should be discouraged across the Nation. Continuous monitoring of municipal water pipeline reticulation should be ensured to prevent incidence of seepage of toxicants such as lead into domestic 
water sources.

\section{Conflicts of Interest}

None of the Authors have conflict of interest.

\section{Availability of Data}

Raw data is available on request at the Department of Zoology Archive, University of Lagos.

\section{Funding}

This project was self funded.

\section{References}

[1] Jideonwo (2014) Ensuring Sustainable Water Supply in Lagos, Nigeria. M.Sc Thesis, University of Pennsylvania, Penn Library, Philadelphia, 161 p.

[2] BBC News (2010) Nigeria-Lead Poisoning Kills 100 Children in North. BBC News.

[3] Independent News \& Media (2010) Lead Poisoning Kills 163 in Nigeria. Independent Online (South Africa).

[4] Zinggl, M. (2016) A Silent Killer: Lead Poisoning in Nigeria: In Aljazeera 2014.

[5] Adeniyi, F.A.A. and Anetor, J.I. (1999) Lead Poisoning in Two Distant States of Nigeria: An Indication of the Real Size of the Problem. African Journal of Medicine and Medical Sciences, 28, 107-112.

[6] World Health Organization (2011) Lead in Drinking-Water. Background Document for Development of WHO Guidelines for Drinking-Water Quality 2011.

[7] Barn, P. and Kosatsky, T. (2011) Lead in School Drinking Water: Canada Can and Should Address This Important Ongoing Exposure Source. Canadian Journal of Public Health-Review, 102, 118-121.

[8] Patrick, L. (2006) Lead Toxicity, a Review of the Literature, Part I: Exposure, Evaluation, and Treatment. Alternative Medicine Review, 11, 2-22.

[9] UNEP (2010) Final Review of Scientific Information on Lead, Version of December. United Nations Environment Programme, Chemicals Branch, DTIE. UNEP, Geneva, Switzerland, 20-78.

[10] Tiwari, S. and Tripathi I. (2012) Lead Pollution-An Overview. International Research Journal of Environmental Science, 1, 84-86.

[11] Tiwari, S., Tripathi, I. and Tiwari, H. (2013) Effects of Lead on Environment. International Journal of Emerging Research in Management \&Technology, 2, 45-51.

[12] Zeqiri, N., Zeqiri, S. and Skenderaj, S. (2012) Blood Pressure Evaluation at the Workers Exposed to Lead. Medical Archives, 66, 92-101. https://doi.org/10.5455/medarh.2012.66.92-93

[13] Hernberg, S. (2000) Lead Poisoning in a Historical Perspective. American Journal of Industrial Medicine, 38, 244-254. https://doi.org/10.1002/1097-0274(200009)38:3<244::AID-AJIM3>3.0.CO;2-F

[14] Nuhu, A.A., Sallau, M.S. and Majiya, M.A. (2014) Heavy Metal Pollutions: The Environmental Impact of Artisanal Gold Mining in Bagega Village Zamfara State, Nigeria. Research Journal of Pharmacological, Biological and Chemical Sciences, 5, 306-314. 
[15] World Water Day (2010) Clean Water for a Healthy World. World Water Quality Facts and Statistics. 510-251-1600X106.

[16] Oluah, N.S. and Ulasi, A.M.O. (2010) Changes in the Haematological Parameters of Clarias gariepinus Exposed to Lead Poisoning. Journal of Fisheries International, 5, 72-76.

[17] Wright, N.J., Thacher, T.D., Pfitzner, M.A., Fischer, P.R. and Petitifor, J.M. (2005) Causes of Lead Toxicity in a Nigerian City. Archives of Disease in Childhood, 90, 262-266. https://doi.org/10.1136/adc.2003.043562

[18] Centres for Disease Control and Prevention (2012) Lead Prevention Tips. http://www.cdc.gov/nceh/lead/tips.htm

[19] Allouche, L., Hamadouche, M., Touabti, A. and Khenrouf, S. (2011) Effects of Long Term Exposure to Low or Moderate Lead Concentrations on Growth Lipid Profile and Liver Function in Albino Rats. Advances in Biological Research, 5, 339-347.

[20] Brunton, L.L., Goodman, L.S., Blumenthal, D., Buxton, I. and Parker, K.L. (2007) Goodman and Gillmans Manual of Pharmocology and Theraupetics. Mcgraw Hill Professional.

[21] Bharali, M.K. (2013) Effects of Acute Lead Acetate Exposure on Liver of Mice. Journal of Global Biosciences, 2, 121-125.

[22] Sherwood, L., Klansman, H. and Yancey, P. (2005) Animal Physiology, Brooks/Cole, Cengage Learning, 2005.

[23] García-Lestón, J., Roma-Torres, J., Vilares, M., Pinto, R., Prista, J., Teixeira, J.P., Mayan, O., Conde, J., Pingarilho, M., Gaspar, J.F., Pásaro, E., Méndez, J. and Laffon, B. (2012) Genotoxic Effects of Occupational Exposure to Lead and Influence of Polymorphisms in Genes Involved in Lead Toxico-Kinetics and in DNA Repair. Environment International, 43, 29-36. https://doi.org/10.1016/j.envint.2012.03.001 